Pacific Journal of Mathematics

THE METRIZATION OF STATISTICAL METRIC SPACE

hold SChweitzer, Abe SKlar and Edward OAKLey Thor 


\title{
THE METRIZATION OF STATISTICAL METRIC SPACES
}

\author{
B. Schweizer, A. Sklar and E. ThorP
}

In a previous paper on statistical metric spaces [3] it was shown that a statistical metric induces a natural topology for the space on which it is defined and that with this topology a large class of statistical metric (briefly, $S M$ ) spaces are Hausdorff spaces.

In this paper we show that this result (Theorem 7.2 of [3]) can be considerably generalized. In addition, as an immediate corollary of this generalization, we prove that with the given topology a large number of $S M$ spaces are metrizable, i.e., that in numerous instances the existence of a statistical metric implies the existence of an ordinary metric. ${ }^{1}$

THeOREM $1 .^{2}$ Let $(S, \mathscr{F})$ be a statistical metric space, $\mathscr{U}$ the twoparameter collection of subsets of $S \times S$ defined by

$$
\mathscr{U}=\{U(\varepsilon, \lambda) ; \varepsilon>0, \lambda>0\},
$$

where

$$
U(\varepsilon, \lambda)=\left\{(p, q) ; p, q \text { in } S \text { and } F_{p q}(\varepsilon)>1-\lambda\right\},
$$

and $T$ a two-place function from $[0,1] \times[0,1]$ to $[0,1]$ satisfying $T(c, d) \geqq$ $T(a, b)$ for $c \geqq a, d \geqq b$ and $\sup _{x<1} T(x, x)=1$. Suppose further that for all $p, q, r$ in $S$ and for all real numbers $x, y$, the Menger triangle inequality.

$$
F_{p r}(x+y) \geqq T\left(F_{p q}(x), F_{q r}(y)\right)
$$

is satisfied. Then $\mathscr{U}$ is the basis for a Hausdorff uniformity on $S \times S$.

Proof. We verify that the $U(\varepsilon, \lambda)$ satisfy the axioms for a basis for a Hausdorff (or separated) uniformity as given in [2; p. 174-180] (or in $\left.\left[1 ; \mathrm{II}, \S 1, n^{\circ} 1\right]\right)$.

(a) Let $\Delta=\{(p, p) ; p \in S\}$ and $U(\varepsilon, \lambda)$ be given. Since for any $p \in S, F_{p p}(\varepsilon)=1$, it follows that $(p, p) \in U(\varepsilon, \lambda)$. Thus $\Delta \subset U(\varepsilon, \lambda)$.

(b) Since $F_{p q}=F_{q p}, U(\varepsilon, \lambda)$ is symmetric.

(c) Let $U(\varepsilon, \lambda)$ be given. We have to show that there is a $W \in \mathscr{U}$ such that $W \circ W \subset U$. To this end, choose $\varepsilon^{\prime}=\varepsilon / 2$ and $\lambda^{\prime}$ so small that $T\left(1-\lambda^{\prime}, 1-\lambda^{\prime}\right)>1-\lambda$. Suppose now that $(p, q)$ and $(q, r)$ belong to

Received June 12, 1959.

1 These considerations have led to the study of $S M$ spaces which are not metrizable as well as to other natural topologies for $S M$ spaces, questions which will be investigated in a subsequent paper.

2 The terminology and notation are as in [3]. 
$W\left(\varepsilon^{\prime}, \lambda^{\prime}\right)$ so that $F_{p q}\left(\varepsilon^{\prime}\right)>1-\lambda^{\prime}$ and $F_{q r}\left(\varepsilon^{\prime}\right)>1-\lambda^{\prime}$. Then, by (1),

$$
F_{p r}(\varepsilon) \geqq T\left(F_{p q}\left(\varepsilon^{\prime}\right), F_{q r}\left(\varepsilon^{\prime}\right)\right) \geqq T\left(1-\lambda^{\prime}, 1-\lambda^{\prime}\right)>1-\lambda .
$$

Thus $(p, r) \in U(\varepsilon, \lambda)$. But this means that $W \circ W \subset U$.

(d) The intersection of $U(\varepsilon, \lambda)$ and $U\left(\varepsilon^{\prime}, \lambda^{\prime}\right)$ contains a member of $\mathscr{U}$, namely $U\left(\min \left(\varepsilon, \varepsilon^{\prime}\right), \min \left(\lambda, \lambda^{\prime}\right)\right)$.

Thus $\mathscr{U}$ is the basis for a uniformity on $S \times S$.

(e) If $p$ and $q$ are distinct, there exists an $\varepsilon>0$ such that $F_{p q}(\varepsilon) \neq 1$ and hence $\varepsilon_{0}, \lambda_{0}$ such that $F_{p q}\left(\varepsilon_{0}\right)=1-\lambda_{0}$. Consequently $(p, q)$ is not in $U\left(\varepsilon_{0}, \lambda_{0}\right)$ and the uniformity generated by $\mathscr{U}$ is separated, i.e., Hausdorff.

Note that the theorem is true in particular for all Menger spaces in which $\sup _{x<1} T(x, x)=1$. However, it is true as well for many $S M$ spaces which are not Menger spaces.

CoRollary. If $(S, \mathscr{T})$ is an SM space satisfying the hypotheses of Theorem 1, then the sets of the form $N_{p}(\varepsilon, \lambda)=\left\{q ; F_{p q}(\varepsilon)>1-\lambda\right\}$ are the neighborhood basis for a Hausdorff topology on $S$.

Proof. These sets are a neighborhood basis for the uniform topology on $S$ derived from $\mathscr{U}$.

THEOREM 2. If an SM space satisfies the hypotheses of Theorem 1, then the topology determined by the sets $N_{p}(\varepsilon, \lambda)$ is metrizable.

Proof. Let $\left\{\left(\varepsilon_{n}, \lambda_{n}\right)\right\}$ be a sequence that converges to $(0,0)$. Then the collection $\left\{U\left(\varepsilon_{n}, \lambda_{n}\right)\right\}$ is a countable base for $\mathscr{U}$. The conclusion now follows from [2; p. 186].

Theorem 2 may be restated as follows: Under the hypotheses of Theorem 1, there exist numbers $\delta(p, q)$ which are determined by the distance distribution functions $F_{p q}$ in such a manner that the function $\delta$ is an ordinary metric on $S$. Loosely speaking, if the statistical distances have certain properties, then certain numerical quantities associated with them have the properties of an ordinary distance. In a given particular case such quantities might be the means, medians, modes, etc.. For example, most of the particular spaces studied in [3] satisfy the hypotheses of Theorem 2, hence are metrizable. Indeed, as was shown in [3], in a simple space, the means (when they exist), medians, and modes (if unique) of the statistical distances each form metric spaces; and similarly, in a normal space, the means of the $F_{p q}$ form a (generally discrete) metric space. What Theorem 2 now tells us is that in many (though not all!) $S M$ spaces we can expect results of this general nature to hold. 


\section{REFERENCES}

1. N. Bourbaki, Topologie générale, Actualités Sci. Ind. 858-1142 (second edition).

2. J. L. Kelley, General Topology, Princeton, 1955.

3. B. Schweizer and A. Sklar, Statistical metric spaces, Pacific J. Math., 10 (1960), 313334.

UNIVERSITY OF CALIFORNIA AT LOS ANGELES

ILLINOIS INSTITUTE OF TECHNOLOGY

Massachusetts Institute of TeChNology 



\section{PACIFIC JOURNAL OF MATHEMATICS}

\section{EDITORS}

David Gilbarg

Stanford University

Stanford, California

F. H. Brownell

University of Washington

Seattle 5, Washington
A. L. Whiteman

University of Southern Californıa Los Angeles 7, California

L. J. PaIge

University of California

Los Angeles 24, California

\section{ASSOCIATE EDITORS}
E. F. BECKENBACH
T. M. CHERRY
D. DERRY

E. HEWITT
A. HORN
L. NACHBIN
M. OHTSUKA

H. L. ROYDEN

M. M. SCHIFFER
E. SPANIER

E. G. STRAUS

F. WOLF

\section{SUPPORTING INSTITUTIONS}

\author{
UNIVERSITY OF BRITISH COLUMBIA \\ CALIFORNIA INSTITUTE OF TECHNOLOGY \\ UNIVERSITY OF CALIFORNIA \\ MONTANA STATE UNIVERSITY \\ UNIVERSITY OF NEVADA \\ NEW MEXICO STATE UNIVERSITY \\ OREGON STATE COLLEGE \\ UNIVERSITY OF OREGON \\ OSAKA UNIVERSITY \\ UNIVERSITY OF SOUTHERN CALIFORNIA
}

\author{
STANFORD UNIVERSITY \\ UNIVERSITY OF TOKYO \\ UNIVERSITY OF UTAH \\ WASHINGTON STATE COLLEGE \\ UNIVERSITY OF WASHINGTON \\ AMERICAN MATHEMATICAL SOCIETY \\ CALIFORNIA RESEARCH CORPORATION \\ HUGHES AIRCRAFT COMPANY \\ SPACE TECHNOLOGY LABORATORIES \\ NAVAL ORDNANCE TEST STATION
}

Mathematical papers intended for publication in the Pacific Journal of Mathematics should be typewritten (double spaced), and the author should keep a complete copy. Manuscripts may be sent to any one of the four editors. All other communications to the editors should be addressed to the managing editor, L. J. Paige at the University of California, Los Angeles 24, California.

50 reprints per author of each article are furnished free of charge; additional copies may be obtained at cost in multiples of 50 .

The Pacific Journal of Mathematics is published quarterly, in March, June, September, and December. The price per volume (4 numbers) is $\$ 12.00$; single issues, $\$ 3.50$. Back numbers are available. Special price to individual faculty members of supporting institutions and to individual members of the American Mathematical Society: $\$ 4.00$ per volume; single issues, $\$ 1.25$.

Subscriptions, orders for back numbers, and changes of address should be sent to Pacific Journal of Mathematics, 2120 Oxford Street, Berkeley 4, California.

Printed at Kokusai Bunken Insatsusha (International Academic Printing Co., Ltd.), No. 6, 2-chome, Fujimi-cho, Chiyoda-ku, Tokyo, Japan.

PUBLISHED BY PACIFIC JOURNAL OF MATHEMATICS, A NON-PROFIT CORPORATION

The Supporting Institutions listed above contribute to the cost of publication of this Journal, but they are not owners or publishers and have no responsibility for its content or policies. 


\section{Pacific Journal of Mathematics}

\section{Vol. 10, No. $2 \quad$ October, 1960}

Maynard G. Arsove, The Paley-Wiener theorem in metric linear spaces ........

Robert (Yisrael) John Aumann, Acceptable points in games of perfect

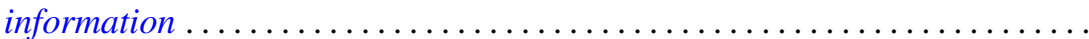

A. V. Balakrishnan, Fractional powers of closed operators and the semigroups generated by them ... . . . . . . . . . . . . . . . . . . . . . . . . . . . . 419

Dallas O. Banks, Bounds for the eigenvalues of some vibrating systems . . . . . 439

Billy Joe Boyer, On the summability of derived Fourier series . . . . . . . . . . . 475

Robert Breusch, An elementary proof of the prime number theorem with

remainder term ...................................

Edward David Callender, Jr., Hölder continuity of $n$-dimensional

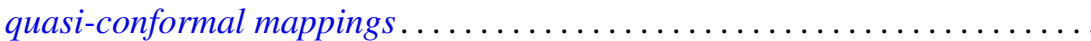

L. Carlitz, Note on Alder's polynomials ......................... 517

P. H. Doyle, III, Unions of cell pairs in $E^{3} \ldots \ldots \ldots \ldots \ldots \ldots \ldots \ldots \ldots \ldots \ldots \ldots . \ldots 21$

James Eells, Jr., A class of smooth bundles over a manifold . . . . . . . . . . . . 525

Shaul Foguel, Computations of the multiplicity function . . . . . . . . . . . . . . 539

James G. Glimm and Richard Vincent Kadison, Unitary operators in

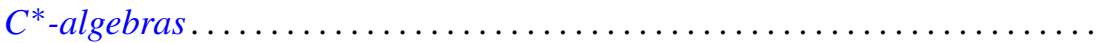

Hugh Gordon, Measure defined by abstract $L_{p}$ spaces . . . . . . . . . . . 557

Robert Clarke James, Separable conjugate spaces ....................

William Elliott Jenner, On non-associative algebras associated with bilinear forms

Harold H. Johnson, Terminating prolongation procedures

John W. Milnor and Edwin Spanier, Two remarks on fiber homotopy type .

Donald Alan Norton, A note on associativity . .

Ronald John Nunke, On the extensions of a torsion module.

Joseph J. Rotman, Mixed modules over valuations rings . . . . .

A. Sade, Théorie des systèmes demosiens de groupoï des . .

Wolfgang M. Schmidt, On normal numbers . .

661

Berthold Schweizer, Abe Sklar and Edward Oakley Thorp, The metrization of

statistical metric spaces

John P. Shanahan, On uniqueness questions for hyperbolic differential

equations

A. H. Stone, Sequences of coverings

Edward Oakley Thorp, Projections onto the subspace of compact operators

L. Bruce Treybig, Concerning certain locally peripherally separable spaces

Milo Wesley Weaver, On the commutativity of a correspondence and a

permutation

David Van Vranken Wend, On the zeros of solutions of some linear complex

differential equations. 